DOI https://doi.org/10.32405/2522-9931-7(36)-209-226

УдК 159.98 - 058.836 .2

\title{
Яцина Олена Федорівна,
}

кандидат педагогічних наук, доцент,

доцент кафедри психології

Державного вищого навчального закладу

«Ужгородський національний університет»,

Ужгород, Україна.

ORCID iD: https://orcid.org/0000-0003-0053-481

yacunaolenafed2017@gmail.com

\section{ПЕРШООСНОВИ ТРАНСФОРМАЦІЙ ПРАКТИК ШЛЮБНО-СІМЕЙНОГО ПАРТНЕРСТВА ТА БАТЬКІВСТВА}

Анотація. На прикладі шлюбно-сімейних практик, як продуктів конструювання реальності певного культурно-історичного простору, розкривається психоісторична реконструкція сім'ї, шлюбу та батьківства. Зазначено, що соціальний зміст сім'ї, вписаний у межі диспозиції сімейності, вказував на її усуспільнення державою, унаслідок чого регулювання здійснюється за допомогою системи ролей, норм, структурно-функціональної організації шлюбно-сімейних практик та контролю за сексуальністю.

Процес індустріалізації, сексуальна революція та жіноча емансипація стали каталізатором змін у поглядах на шлюб, сім'ю та батьківство. На думку автора, лібералізація сексуальних стосунків у контексті історичних подій того часу спрямовувалася на руйнування «буржуазної» сім'ї як соціальної одиниці та на егалітарні експерименти: комуни, вільну любов i легітимізацію практик мономатеринської сім'ї. Наголошено, що сексуальні стосунки без подальшого укладання шлюбу і продовження роду - батьківства виявили нестійкість матриці «диспозиція сімейності», що розглядається як початок процесу її деконструкції. Відмежування сексуальних стосунків від репродуктивної функції залишало практики сексуального партнерства поза диспозицією сімейності, у такий спосіб закладаючи нові правила культури поведінки у сфері шлюбносімейних стосунків.

Визначено, що прогностично інформативними ознаками трансформації практик шлюбно-сімейного партнерства та батьківства $є$ соціальнопсихологічні предиктори смислів практик: культурно-обумовлені, індивідуально-особистісні, емоційно-чутливі.

Висновок: диспозиція сімейності, як матриця конфігурацій культивованих суспільством практик сім'ї, шлюбу та батьківства, в 
умовах іншої соціальності змінюється. Функціонування практик цивільного партнерства та мономатеринських сімей виявило розрив зв'язків сексуальність - репродуктивність та шлюб - батьківство, що розглядаються як сигнали інституціональних перетворень сім'ї, шлюбу та батьківства. Відмежування сексуальних практик від диспозиції сімейності в історичній перспективі уможливило конструювання конфігурацій, де розрив зв'язку стать - гендер не тільки урізноманітнив функціонально-рольові стосунки чоловіків/жінок, а й підкреслив глибину змін інститутів сім'ї, шлюбу та батьківства.

Ключові слова: диспозиція сімейності; практики; цивільне партнерство; мономатеринська сім'я; стать; гендер.

\section{1. ВСТУП / INTRODUCTION}

Постановка проблеми. В умовах постмодерну увага дослідників поширюється на опис соціально-психологічних практик як засобів «життєтворення», пов'язаних із власною інтерпретацією соціальності. Посилання на аналіз трансформацій практик шлюбно-сімейного партнерства та батьківства базується на причинах, які актуалізують проблему, пов'язану, насамперед, із впливом глобальних суспільних трансформаційних процесів, що позначаються у конструюванні поліфонії смислів практик, як це легітимується постмодерном. Коли міркуєш про сучасний розвиток цивілізації, то увагу привертають процеси, в яких соціальні норми втрачають/втратили свою безумовну актуальність, припиняють/припинили бути релевантними у конструюванні сімейних практик. Своєрідною відповіддю на рефлексивне осмислення суспільних процесів $\epsilon$ багатоманітність практик сім'ї, шлюбу та батьківства. Розуміння особливостей їх трансформацій $є$ актуальним дослідницьким завданням, 3 огляду на яке звернення до аналізу реконструйованих шлюбно-сімейних практик дасть змогу з'ясувати першооснови трансформацій сім'ї, шлюбу та батьківства.

Як зауважує А.Флієр, «природний i культурний досвід людства об'єктивно передує соціальному індивіду і приймається ним» [20, с. 203]. У цьому сенсі сім'я та шлюб $є$ культурною складовою формування стосунків між чоловіком і жінкою, характеризуються певними культурними кодами i смислами, конкретизованими у продовженні роду і зміцненні матеріального статку, інтерпретуються як об'єктивно визначені природою та соціальним устроєм.

Тому логічно постає проблема з'ясування першооснов трансформацій практик шлюбно-сімейного партнерства та батьківства, різноманітно представлених у соціальній реальності. Зважаючи на це, означені питання 
Вісник післядипломної освіти. Випуск 7(36) «Серія «Соціальні та поведінкові науки» https://doi.org/10.32405/2522-9931

вимагають подальшого дослідження, особливо у контексті виявлення тенденцій перетворень в інститутах сім'ї, у шлюбі, батьківстві, партнерстві, що уможливить ефективний психологічний супровід подружжя/партнерів 3 боку психологів і соціальних працівників.

Аналіз останніх досліджень і публікацій. Соціально-психологічний зміст понять «сім'я», «шлюб», «батьківство» розглядається у різних соціальних контекстах. Теоретичний аналіз вказує, що наукові розвідки здійснюються переважно в межах структурно-функціональної теорії та теорії символічного інтеракціонізму з акцентуванням на сутності сім'ї як процесу взаємодії, де входження людини до структури шлюбно-сімейних зобов'язань робить подружні стосунки соціально визначеними, забезпечуючи почуття суб'єктивного добробуту їі членів. Дослідники, наголошуючи на тому, що суб'єктність індивіда в сім'ї, індивідуалізація поведінкових стратегій чоловіків і жінок в умовах спільного проживання зростають, доводять у такий спосіб активність індивіда щодо перетворення буття, що відповідає його внутрішньому змісту (К. Абульханова-Славська, Б. Ананьєв,
А. Брушлинський,
А. Журавльов,
С. Нартова-Бочавер,
С. Рубінштейн, А. Тиводар та ін.). Зокрема у контексті суб'єктного підходу як продовженні традицій гуманістичної інтерпретації особистості увага зосереджується на перетворенні реальності зовнішнього світу відповідно до структури сконструйованих особистісних смислів, які можуть сприяти або перешкоджати інтенції самоактуалізації. Наприклад, у концепції, запропонованій А. Тиводар, особистість, як суб'єкт шлюбного співбуття 3 Іншим, $\epsilon$ саме тим середовищем, в якому людина із притаманною їй інтенцією самоактуалізації у спосіб, який сама вибирає, намагається «відбутися в усій повноті свого потенціалу» [19, с. 23]. Зазначається, що в обставинах співбуття 3 Іншим особистість селекціонує можливі види активності, можливі соціальні ролі, можливі ідентичності і намагається об'єктивувати свою суб'єктивність [19]. Дослідниця вважає, що суб'єктнобуттєвий підхід підкреслює спрямованість людини на перебудову буття відповідно до структури особистісних смислів, тобто на перетворення реальності зовнішнього світу так, що вона (реальність) стає наслідком об’єктивування суб'єктивного. Зауважимо, що зазначений підхід суперечить положенням конструкціонізму, у контексті яких розглядається проблема нашого дослідження.

Ю. Савельєва, усупереч «сталій моделі сім'ї як структури», вказує на визначальність «процесуального характеру сім'ї (сім'єутворення)». Слушною $€$ думка про те, що «онтологія стосунків прийшла на зміну ствердженню субстанціональних якостей, оскільки точкою відліку є не суб'єкт зі своїми субстанціональними якостями, а ті взаємини, які ним вибудовуються» [18, c.29]. Процесуальний аспект життя сім'ї підкреслюється і в публікації 
Д. Кутузової, де наголошується на тому, що, на відміну від традиційно прийнятих у психології і соціології структурно-функціональних визначень сім'ї, соціальний конструкціонізм вважає, що «уявлення про сім'ю конструюються людьми 3 урахуванням умов часу, місця і соціального контексту» [12]. Дослідниця наголошує на тому, що постмодерністські підходи уможливлюють дистанціювання від звичної стурбованості структурою і функціями сім'ї на користь різноманітних варіантів переживання того, що означає «бути сім'єю» [12].

Отже, огляд джерел ілюструє різні підходи до вивчення визначеної проблематики, і це допомагає констатувати, що в постмодерністському контексті практики шлюбно-сімейного партнерства та батьківства вже не можуть розглядатися як категорії, які можна точно визначити і пояснити, зосереджуючись на одній «абсолютній» парадигмі. Насправді, досліджувані практики, виходячи із постмодерної ідеї множинності й різноманітності, співіснування неоднорідних елементів, підлягають лише інтерпретаціям, в яких поєднується все поєднуване і непоєднуване: гетеронормативність і гомосексуальність, патріархальність і плюралізм, гедонізм і прагматизм, чутливість і раціональність, укоріненість і різноманітність, гра смислами і бажаннями, традиція й епатаж, реальне і віртуальне, глобальне і локальне, соціальне й особистісне, публічне і приватне.

\section{2. МЕТА ТА ЗАВДАННЯ / AIM AND TASKS}

Мета статті полягає у теоретичному аналізі першооснов трансформацій практик шлюбно-сімейного партнерства та батьківства.

Відповідно до зазначеної мети у статті поставлено завдання: виявити чинники деконструкції диспозиції сімейності, що в історичній перспективі уможливили конструювання різних конфігурацій практик сім'ї, шлюбу, батьківства та партнерства.

\section{TЕОРЕТИЧНІ ОСНОВИ ДОСЛІДЖЕННЯ / THЕ THЕORETICAL BACKGROUNDS}

Під впливом глобальних суспільних трансформаційних процесів змінюються мотиви, структура сім'ї, шлюбу, батьківства, партнерства та функціонально-рольова взаємодія подружжя/партнерів. Зважаючи на це, функціонування різноманітних практик шлюбно-сімейного партнерства та батьківства $є$ ознакою їх легітимації, що позначається у змінах соціальних інститутів сім'ї, шлюбу, батьківства і може означати початок формування соціально-психологічного підгрунтя для інституціоналізації практик партнерства, утворених на інших засадах: опозиції до гетеронормативності як метанорми у стосунках подружжя/партнерів, розриві зв'язків стать - 
гендер - ідентичність та продукуванні ризоматичних конструкцій практик шлюбно-сімейного партнерства та батьківства.

Тому важливим аспектом проблемного поля дослідження, що грунтується на основі постмодерністського принципу поліваріативності, $\epsilon$ з'ясування сутності, особливостей та закономірностей конструювання i функціонування практик шлюбно-сімейного партнерства та батьківства, що допомагає окреслити зміст трансформаційних перетворень у соціальній реальності.

\section{4. МЕTОДИ ДОСЛІДЖЕННЯ / RESEARCH METHODS}

Для вирішення поставленої мети використано теоретичні методи наукового дослідження: аналіз сучасного стану досліджуваної проблеми у соціальній психології та реконструкцію історичної соціально-культурної реальності диспозиції сімейності як матриці конфігурацій, культивованих суспільством практик.

\section{5. РЕЗУЛЬТАТИ ДОСЛІДЖЕННЯ / RESEARCH RESULTS}

Психоісторична реконструкція сім'ї, шлюбу та батьківства, що полягає у відтворенні певних історичних типів поведінки, мислення, сприйняття [1], здійснена на прикладі шлюбно-сімейних практик як продуктів конструювання реальності певного культурно-історичного простору, розкриває взаємозумовленість між мотивами укладання шлюбу та ролями, функціонально закріпленими за чоловіками/жінками. Розширена сім'я, утворена на соціальній конвенції, головну мету вбачала у продовженні і збільшенні роду, зміцненні його економічної складової. Інструментом слугувала функціонально-рольова дихотомія чоловічого/жіночого, що у такий спосіб запроваджувало чоловічу владу й створювало сім'ю з такими соціально-психологічними феноменами, як гендерний розподіл ролей, стереотипи маскулінності/фемінінності та сексуальності. У такий спосіб створювалася соціальна реальність, в якій було наперед визначено стосунки між чоловіком і дружиною, відтворювався «чоловічий габітус», «матриця сприйняття, мислення та дії, яка нав'язувалася всім членам суспільства, генеруючи виразний розподіл статей, різниці між ними та зумовлені цим місця у символічних сферах, які забезпечували чоловікові домінантну позицію, а жінці - підлеглу» [24, с. 101]. Отже, «чоловічий габітус» охоплював завдання, пов'язані із відповідальністю за добробут сім'ї, зокрема за її захист, що зміцнювало право на владу та виправдовувало дихотомію чоловіче/жіноче. Як справедливо зазначає О. Рождественська, «життя відповідно до «чоловічого габітусу породжує почуття габітусної впевненості/безпечності в межах певного соціального порядку» $[17$, с. 93]. 
Вісник післядипломної освіти. Випуск 7(36) «Серія «Соціальні та поведінкові науки» https://doi.org/10.32405/2522-9931

Репродуковані в межах релігійного і владного дискурсів, ієрархізовані стосунки у сім'ї не суперечили процесам іï усуспільнення, що відбулися на публічності особистого й сімейного життя та контролі над сексуальністю. У масовому дискурсі вони відтворювали традиційні уявлення, укорінені на функціонально-рольовій організації патріархального укладу сім'ї. За теорією М. Фуко, це означало відокремлення сексуальних бажань від людського тіла, насамперед, жіночого, з яким пов'язується природна функція репродукції [21, c. 134].

За висновками дослідників, каталізатором змін у поглядах на шлюб, сім'ю та батьківство є процеси індустріалізації, сексуальна революція та жіноча емансипація. Зокрема, на думку С. Гаврова, в епоху модерну відбулася велика демографічна революція, що була частиною вивільнення жінки від служіння церкві, кухні і дітям [4]. Важливим етапом цього періоду, на думку П. Куусі, став перехід до «свідомого контролю над народженням. У такий спосіб жінки вивільнилися від нав'язаного їм талану і обов'язків примусового дітонародження» $[10$, с. 210]. 3 цього робимо висновок, що сексуальна революція несла психологічне вивільнення жінок від сімейного «рабства», $\mathrm{i}$ це надавало їм право самим вирішувати, коли і скільки народжувати дітей, коли навчатися, працювати, брати участь у громадських справах, уможливлюючи процес самореференції ідентичностей як у межах шлюбних стосунків і сімейних обов'язків, так і поза ними.

Як зауважують дослідники, після революції 1917 р. в Росії тема «природності» фізіологічної привабливості протилежної статі й необхідності негайного задоволення сексуальних потреб, як показника вивільненої революційної свідомості [5], активно підхоплювалася молоддю, котра ставилася до шлюбу як до анахронізму і виступала за нетривалі любовні зв'язки. Ю. Градскова відзначає: «"Статева рівність у коханні" полягала у створенні вільного союзу чоловіка і жінки» [5]. Це дає змогу зауважити, що саме у таких мовних конструктах утворювалася диспозиція сексуальності. Символічним вивільненням від моногамії можна вважати створення комун, де полігамні стосунки мали формувати уявлення про рівність чоловіків і жінок. Проте взаємини у комуні часто грунтувалися на ієрархічних конструкціях чоловічої свідомості, що проявлялося у вимогах до жіноктоваришок виконувати «сімейні обов'язки» [5].

Період із середини 1920-х до початку 1930-х рр. на теренах тодішнього Радянського Союзу характеризується «ліберальним законодавством і легітимацією ряду заборонених в імперський період індивідуальних, зокрема сексуальних, прав і свобод» [6, с. 2-3]. Поряд із розширеною та нуклеарною (подружньою) сім'ями, «узаконюється» цивільний шлюб (зрідка використовується поняття «конкубінат») - спільне проживання чоловіка і жінки, стосунки між якими юридично не оформлено. Згідно з Кодексом про 
шлюб, сім'ю та опіку, затвердженим у 1926 р., реєстрація шлюбів була проголошена необов'язковою, позаяк Кодекс визнавав легітимними фактичні шлюби, яким відповідали такі умови: «факт спільного проживання, наявність при цьому спільного господарства і вияв подружніх стосунків перед третіми особами в особистому листуванні та інших документах, а також, залежно від обставин, взаємна матеріальна підтримка, спільне виховання дітей тощо» $[23$, с. 216]. У цій частині зауважимо, що поняття «цивільний шлюб», на нашу думку, некоректно співвідноситься зі шлюбними практиками як законно утвореними шлюбними союзами. На цій підставі використовуватимемо поняття «цивільне партнерство», що відповідає змісту стосунків чоловіків/жінок і характеру їхнього співпроживання в парі.

Утворення практик цивільного партнерства, на нашу думку, вмотивовано не тільки суб'єктивним бажанням вільних сексуальних стосунків, переживанням задоволення і насолоди. Глибшою причиною вважаємо те, що лібералізація сексуальних стосунків у контексті історичних подій спрямовувалася на руйнування «буржуазної» сім'ї як соціальної одиниці, яка відтворювала патріархальні імперські уявлення, норми й оцінки, котрі регулювали поведінку членів сім'ї в побуті. За оцінкою фемінізму, патріархат - це «система влади, за якої саме чоловікові належить верховна влада й економічні привілеї... Зокрема чоловіки контролюють жіночу сексуальність і домінують у соціальних інституціях, що призводить до знецінення ролі жінок та їхньої підпорядкованості», - зазначає З. Кодар $[11$, c. 452].

Отже, ставлення чоловіка до жінки і жінки до чоловіка, побутові моделі поведінки в сім'ї, що вкорінювалися і перетворювалися на систему сімейних цінностей та ієрархію, протиставлялися сексуальній свободі та радикальній рівності й проголошувалися для того, щоби знищити «буржуазний» інститут сім'ї і показати його ідеологічну зумовленість. 3 іншого боку, нормам гетеросексуальності та моногамії протиставлялися егалітарні експерименти: комуни та вільна любов. Зазначене, на нашу думку, указує на процеси розмивання традиційних шлюбно-сімейних практик, знецінення диспозиції сімейності як матриці конфігурацій практик та творення практик на засадах свободи стосунків і рівності статей.

Водночас «радянська держава залишає за собою значну сферу прямого й активного втручання у сімейні взаємини та відкидає погляд на стосунки між статями як на індивідуальні, особисті, нейтральні для суспільства i держави», - констатує Н. Лебіна [13]. Зміст зазначеного може інтерпретуватися по-різному. 3 одного боку, це може означати відкритість теми приватності сімейного, інтимності особистого життя для публічного обговорення. 3 іншого, може полягати у контролі за сексуальністю, що, за М. Фуко, $\epsilon$ чинником створення «соціально-політичної "мішені"», яку влада 
виділяла для упорядкування практик підкорення: жінка-мати, дитина, яка виявила в собі сексуальність, подружжя, гомосексуальний індивід [19, с. 208]. Отже, соціальний зміст сім'ї, вписаний у межі диспозиції сімейності, вказував на іiї усуспільнення державою, де регулювання здійснюється за допомогою системи ролей, норм, структурно-функціональної організації шлюбносімейних практик. Характер такого зв'язку між сім'єю і державними інститутами було сформульовано в афоризмі «Міцна сім'я - міцна держава», в якому через сенс домінуючого концепту «міцність» передавалася ідея контролю, ієрархії, порядку, влади, що закріплювалися інституцією.

Попри таке загальне розуміння інститутів як конструктів, що склалися внаслідок послідовно здійсненої об’єктивації реальності, Т. Парсонс вбачав у них сукупність специфічних нормативних комплексів, задіяних у процесі регуляції статусно-рольової поведінки індивідів [15]. П. Бергер зазначав, що «це загальноприйняте вживання надто однобоке: воно занадто пов'язує поняття інституції з тими соціальними сутностями, котрі визнаються та кодифікуються правом» [3]. Зосереджуючи увагу на базових характеристиках інституцій, дослідник виокремлює серед них такі, як: екстернальність, об'єктивність, спонукальну силу, моральний авторитет та історичність. Під терміном «інституція» розуміється встановлення, традиція, порядок, заведений у суспільстві, а «інститут» відповідно $є$ системою закріплення звичаїв і порядків як суспільної норми. Логіка обгрунтування простежується за допомогою невід'ємних характеристик, які певною мірою відрізняються від ознак інституцій та наголошують на організаційних формах їх функціонування. Серед них важливою характеристикою інституту визнається історичність: інститути позиціонуються як певний кінцевий продукт історичного розвитку суспільної сфери. Іншими, не менш важливими, ознаками інституту, вважається їх структурність та функціональність. Структурність слугує підтвердженням того, що кожен інститут існує як наслідок взаємодій з іншими інститутами соціальної системи. Функціональність означає, що інститути існують доти, допоки виконують визначені для них суспільством функції, сприяючи інтеграції суспільства й досягненню гомеостазу [9].

Отже, зміст поняття інституту сім'ї охоплює систему сімейних цінностей, приписів, нормативної поведінки подружжя, соціальних ролей як наслідку соціальної конвенції внаслідок впливу культури і традицій. Попри те що зовнішній вияв інститутів проявляється через правове закріплення норм, глибинний вияв вони знаходять у цінностях, що існують у соціумі. За твердженням П. Рікера, інституції $\epsilon$ ні що інше, як віддзеркалення стану волі та почуттів певної людської групи в певний період історії; інституції - то завжди абстрактний знак, який ще треба розшифрувати [15, с. 302]. Г. Бевз виходить із традиційного розуміння соціального інституту як засобу 
врегулювання певного виду людської діяльності [2, с.9], як механізму соціального контролю [2, с. 24], як сукупності соціальних зв'язків соціальних суб'єктів, що забезпечують створення та підтримку відчуття цілісності певної спільноти, орієнтованої на досягнення певних соціальних цілей соціальної системи загалом [2, с. 30].

Отже, інституціям відводиться значення символічних, звичаєвих, семіотичних значень та практик, закріплення i відтворення яких здійснюється за допомогою таких соціальних утворень, як соціальні інститути сім'ї, шлюбу, батьківства.

Повертаючись до тези М. Фуко щодо контролю як чинника створення «соціально-політичної "мішені"», зупинимося на «мішені» жінка-матір. Образ жінки обмежувався рамками диспозиції сімейності, де їй надавався статус дружини, а дітям - законність їхнього народження. Це, на думку С. Чуйкіної, робило жінку найбільш «уразливим об'єктом державних тілесних практик» $[22$, с. 112]. В індустріалізованому суспільстві їй готували роль «радянської жінки-трудівниці», для якої суспільні інтереси мали важити більше за сімейні, а почуття материнської прихильності до дитини мало поступитися місцем виробничій активності та суспільним інтересам [22]. Отже, у диспозиції сімейності концепт материнства змінюється: держава забезпечує жінці-матері соціальну підтримку. Вона виявляється у тому, що репродуктивна функція (власне, виношування i народження дитини) відокремлюється від інших соціально-психологічних функцій феномену материнства. Історичним чинником стало створення державної системи утримання, навчання і виховання дітей, починаючи з раннього віку. Догляд і виховання перебирали державні інституції: дошкільні та шкільні заклади освіти, що забезпечували цілодобовий нагляд за дітьми в яслах та дитячих садках у той час, яке жінка виконувала покладені на неї обов'язки «радянської трудівниці». Показово, що активність жінки-трудівниці була причиною зниження народжуваності, що стало поштовхом до введення «репресивного законодавства стосовно сім'ї, сексуальності та відповідальності жінок і чоловіків за сексуальні стосунки і батьківство» [22].

У післявоєнні 1950-ті рр. сімейна політика СРСР «збагатилася» указом, за яким правове значення мали тільки зареєстровані шлюби (при цьому особи, що були у цивільному (фактичному) шлюбі в період з 1926 по 1944 рр., повинні були зареєструвати стосунки, за інших умов шлюб оголошувався недійсним). Це пояснюємо як спробу збереження/відновлення структури нуклеарної сім'ї, зруйнованої війною.

Проте заборона встановлення батьківства щодо дітей, народжених не в шлюбі, після відміни імперських законів у 1917 р. фактично закріпила як норму статус «незаконнонародженого», тому що ці діти не могли отримати прізвище батька (навіть коли останній давав згоду). Тобто легітимізувалася 
практика мономатеринської сім'ї, що складалася з матері і дитини/дітей. Утім, аби надати їй та цивільному партнерству значення «небажаних» практик, що суперечать диспозиції сімейності, інституціональності сім'ї, де батьківство затверджується шлюбом, одночасно виникло поняття «неповна» сім'я із закріпленням за дітьми, народженими в ній, статусу «незаконнонароджених», а за жінками - статусу «матері-одиначки». Це, на нашу думку, стало початком соціальної стигматизації як реакції на «ненормативну» поведінку жінок, дії яких не вписувалися у поняття сімейності. На жаль, відлуння такого негативного маркування жінок і дітей, народжених поза шлюбом, затягнулося на десятки років.

Отже, держава у різний спосіб намагалася «зміцнювати» інститут сім'ї, в якому від'єднанням батьківства від шлюбу почався процес деконструкції диспозиції сімейності, що означає руйнування норм і стереотипів у поглядах на шлюб і батьківство та практикування мономатеринських сімей, цивільних партнерств, вільних союзів, котрі не відповідають нормам інституціонального дискурсу.

Поглиблення процесу деконструкції було зумовлене так званою сексуальною революцією 1960-х рр. на Заході, що пропагувала дискурс вільних статевих стосунків та питання контрацепції, котре було активно підтримане не тільки серед молоді, яка вступала у статеві стосунки без наміру створювати сім'ю, а й серед подружніх пар. Сексуальні стосунки стають інструментом отримання задоволення, насолоди, досвіду, у такий спосіб урізноманітнюючи практики партнерства. Поряд із поняттям «сексуальне задоволення», з'являється поняття «сексуальне незадоволення», що виражає негативну оцінку сексуальними аспектами стосунків, умотивовуючи розірвання шлюбу. Важливо наголосити, що сексуальні стосунки без подальшого укладання шлюбу і продовження роду батьківства - виявили нестійкість матриці «диспозиція сімейності», зумовленої розривом між сексуальністю і репродукцією, увиразненою у практиках цивільного партнерства і вільних союзах. Отже, відмежування сексуальних стосунків від репродуктивної функції залишало практики сексуального партнерства поза диспозицією сімейності, закладаючи в такий спосіб нові правила культури поведінки у сфері шлюбно-сімейних стосунків.

Зазначене дає змогу стверджувати, що функціонування практик цивільного партнерства та мономатеринської сім'ї в умовах іншої соціальної реальності стало початком розмивання меж традиційної сім'ї, руйнуванням цілісності інститутів сім'ї, шлюбу й батьківства. Фіксація партнерів/подружжя на розмежуванні сексуальності і репродукції дає змогу розглядати їх як першооснови трансформації інститутів сім'ї, шлюбу та батьківства. 3 цього робимо висновок, що створення практик цивільного партнерства та мономатеринської сім'ї стало початком зміни соціальних 
Вісник післядипломної освіти. Випуск 7(36) «Серія «Соціальні та поведінкові науки» https://doi.org/10.32405/2522-9931

норм сім'ї, шлюбу й батьківства як стабільних та універсальних, невід'ємних елементів фонового розуміння, що мали означати неінтенціональну схильність сприймання, оцінювання, дії, детерміновану соціокультурним контекстом.

Ми вже згадували твердження Л. Моргана про активне начало сім'ї, що забезпечує її зміни в міру того, як розвивається суспільство. Це надає право вважати, що на мінливість сім'ї, як соціального інституту, впливають як макрозміни соціальності, так і мікрозміни - суб'єктивність/ідентичність. Особливості процесів постмодерної соціальності дослідники розкривають у терміні «глокалізація», що характеризується одночасною присутністю у сучасному соціальному просторі процесів локалізації і ситуації розгортання глобальних вимірів [7]. 3 пояснень 0. Олійника, основою процесу глокалізації $\epsilon$ глобалізація локального і локалізація глобального, що, з одного боку, означає відтворення елементів загального в конкретних спільнотах, злиття усталених меж, а з іншого - це пошук конкретних відмінностей, якісно нового та відмінного від інших, підкреслення власної ідентичності та винятковості [14]. Як зазначає дослідник, локальні ситуації трансформуються, стаючи частиною ширших глобальних систем та процесів, у той самий час глобальні аспекти отримують нове значення у специфічних локальних умовах [14]. Послуговуючись поняттям «глокалізація», розуміємо його як початок процесу локалізації глобальних змін інститутів сім'ї, шлюбу та батьківства, глобалізацію локальних перетворень у шлюбно-сімейних практиках, пов'язану із конструюванням практик, де підкреслюється індивідуальність їх смислів і значення локальних комунікативних ситуацій та можливість самореференції в них різних типів ідентичностей.

У нашому дослідженні на мікрорівні - у ПШСПБ - це відбивається на функціональній взаємодії подружжя/партнерів, батьківстві. Як уже було зазначено, у постмодерній соціальності традиційні сім'я, шлюб та батьківство втрачають значення метанаративних моделей подружньої взаємодії і конструюють різні змісти, що призводить до глобальних трансформацій соціального інституту сім'ї: руйнування інституціональних принципів організації сім'ї, шлюбу, партнерства та батьківства. Об'єктивно зміни пов'язані із приватною власністю, суспільним виробництвом, секуляризацією сімейного життя, жіночою емансипацією та сексуальною революцією. На цьому тлі змінюється розуміння чоловіками/жінками своєї суб'єктивності/ ідентичності та смислів вибудуваних стосунків як подружжя/ партнерів. Зокрема в контексті вищезазначеного, суб'єктивність, названа I. Жеребкіною основним параметром жіночої життєвої реальності [8], на нашу думку, повною мірою реалізується в мономатеринській сім'ї, де материнство домінує над шлюбністю. Останнє стає важливою зміною 
Вісник післядипломної освіти. Випуск 7(36) «Серія «Соціальні та поведінкові науки» https://doi.org/10.32405/2522-9931

суб’єктивності жінки, яка в диспозиції сімейності сприймалася пасивною та підкореною владі чоловіка.

\section{6. ВИСНОВКИ ТА ПЕРСПЕКТИВИ ПОДАЛЬШИХ ДОСЛІДЖЕНЬ / CONCLUSIONS AND PROSPECTS FOR FURTHER RESEARCH}

Отже, здійснений аналіз виявив, що диспозиція сімейності, як матриця конфігурацій культивованих суспільством практик сім'ї, шлюбу та батьківства, в умовах іншої соціальності змінюється. Функціонування практик цивільного партнерства та мономатеринських сімей виявило розрив зв'язків сексуальність - репродуктивність та шлюб - батьківство, що розглядаються нами як сигнали інституціональних перетворень сім'ї, шлюбу та батьківства. Відмежування сексуальних практик від диспозиції сімейності в історичній перспективі уможливило конструювання конфігурацій, де розрив зв'язку стать - гендер не тільки урізноманітнив функціональнорольові стосунки чоловіків/жінок, а й підкреслив глибину змін інститутів сім'ї, шлюбу та батьківства.

Перспективи подальших досліджень. Представлені результати досліджень $\epsilon$ початком дослідження постмодерних трансформацій практик шлюбно-сімейного партнерства та батьківства. Серед перспективних напрямів подальших досліджень - розроблення теоретичної моделі трансформації практик шлюбно-сімейного партнерства та батьківства.

\section{7. СПИСОК ВИКОРИСТАНИХ ДЖЕРЕЛ}

[1] И. Г. Белявский, Лекции по исторической психологи. Одесса, Украина: Астропринт, 2004, 448 с.

[2] Г. М. Бевз, Прийомна сім'я: соціально-психологічні виміри. Київ, Україна: Слово, 2010, 352 с.

[3] П. Л. Бергер, Б. Бергер, Що таке інституція? Випадок мови, Незалежний культурологічний часопис «ё», № 35, 2004; пер. Ю. Яремко. [Електронний pесурс]. Доступно: http://www.ji.lviv.ua/n35texts/35-zmist.htm.

[4] С.Н.Гавров, Историческое изменение институтов семьи и брака. Москва, Россия: НИЦ МГУДТ, 2009, 134 с.

[5] Ю. В. Градскова, Обычная» советская женщина - обзор описаний идентичности. Москва, Россия: Sputnik, 1998, с. 362-364. [Электронный ресурс].

Доступно: http://kaznu.kz/content/files/pages/folder18187/Ю.В.\%20Градскова\%20 -\%200бычная\%20советская\%20женщина\%20.pdf

[6] С. В. Дармодехин, «Семья и государство», Мониторинг социальноэкономического потенциала семей, № 3, с. 2-3, 2000. 
Вісник післядипломної освіти. Випуск 7(36) «Серія «Соціальні та поведінкові науки» https://doi.org/10.32405/2522-9931

[7] Н. Є.Доній, «Соціальна девіталізація особистості в глобалізованому світі: філософська концептуалізація», автореф. дис. д-ра наук; М-во освіти і науки України; Нац. пед. ун-т ім. М. П.Драгоманова. Київ, Україна, 2015, 36 с.

[8] И. Жеребкина, Субъективность и гендер: гендерная теория субъекта в современной философской антропологии. Санкт-Петербург, Россия, 2007, c. 260.

[9] М. Кармазіна, О.Шурбована, «"Інститут" та "інституція": проблема розрізнення понять». Політичний менеджмент, № 4, с. 10-19, 2006.

[10] Т.Г. Киселева, Женский образ в социокультурной рефлексии. Москва, Россия: МГУКИ, 2002, с. 210.

[11] 3. М. Кодар, «Представители французского феминизма о ценности женского начала», на II Междунар. заоч. науч.-практ. конф. Гендерные аспекты гуманитарных наук (Россия, г. Новосибирск, 21 ноября 2012 г.) [Электронный ресурс]. Доступно: https://sibac.info/conf/gender/iiii/30157

[12] Д.А. Кутузова, «Быть семьей»: взгляд с точки зрения социального конструкционизма», Постнеклассическая психология. Социальный конструкционизм и нарративный подход, № 1(2), с. 72-93, 2005. [Электронный ресурс]. Доступно: http://narrativepsy.narod.ru/num12005.html

[13] Н.Б. Лебина, М.В. Шкаровский, «В отсутствие официальной проституции», Проституция в Петербурге (40-е гг. XIX в. - 40-е г2. XX в.). Москва, Россия: Прогресс-Академия, 1994, 288 с., с. 40-59; 98-132.

[14] О. М. Олійник, «Глокалізація як діалектична єдність глобалізації та локалізації» Гілея: науковий вісник: зб. наук. праць. № 24, с. 167-173, 2009. ISSN 2076-1554.

[15] Т. Парсонс, O социальных системах. Москва, Россия: Академический проект, 2002, 832 c.

[16] Поль Рікер, Історія та істина; пер. з фр. В. І. Шовкун; Т. С. Голіченко, Ред. Київ, Україна: КМ Academia: Пульсари, 2001, 393 с.

[17] Е. Ю. Рождественская, «Неформализованные данные: методы сбора и анализа. Документальный доступ к «субъективным микротеориям» и обыденному знанию», Социология, № 33, с. 80-111, 2011. [Электронный ресурс].

Доступно: http://jour.isras.ru/upload/journals/6/articles/3722/submissio n/original/3722-6895-1-SM.pdf

[18] Ю. М. Савельєва, «Соціально-філософське осмислення сімейних зв’язків в епоху мережевого суспільства: схід проти заходу», Теорія і практика управління соціальними системами, № 1, с. 29-35, 2015. 
[19] А. Р. Тиводар, «Личность как субъект со-бытия в брачных отношениях: автореф. дис. на соискание ученой степени д-ра наук»; Кубанский гос. ун-т. Краснодар, Россия, 2008, 47 с.

[20] А.Я. Флиер, Культурология для культурологов. Москва, Россия: Академический Проект, 2000, 496 с. ISBN 5-8291-0083-5

[21] М. Фуко, История сексуальности-III: Забота о себе. Пер, с фр. Т. Н. Титовой и О. И. Хомы; А. Б. Мокроусова, Ред. Киев, Украина: Дух и литера; Грунт; Москва, Россия: Рефл-бук, 1998, 288 с. (Astrum Sapientiale).

[22] С. Чуйкина, «Быт неотделим от политики: официальные и неофициальные нормы половой морали в советском обществе 19301980-х годов», В поисках сексуальности: сборник статей. Е. Здравомысловой и А. Темкиной. Ред. Санкт-Петербург, Россия, 2002, c. 112.

[23] Е.В.Якимова, «Социально-психологические аспекты семьи и брака: теория и эмпирия», Человек: образ и сущность. Ежегодник. Семья: Традиции и современные тенденции, РАН. ИНИОН, с. 215-243, 2007:

[24] P. Bourdieu, Męska dominacja / Tłum. L. Kopciewicz. Warszawa, 2004, s. 101.

\title{
FUNDAMENTAL PRINCIPLES OF TRANSFORMATIONS OF SOCIO-PSYCHOLOGICAL PRACTICES OF MARRIAGE AND FAMILY PARTNERSHIP AND PATERNITY
}

\author{
Olena Yatsyna, \\ Candidate of Pedagogic Science, Assistant Professor of the \\ Department of Psychology, Uzhgorod State National University, \\ Uzhgorod, Ukraine. \\ ORCID iD: https://orcid.org/0000-0003-0053-481 \\ yacunaolenafed2017@gmail.com
}

Abstract. On the example of marriage and family practices as products of constructing the reality of a certain cultural-historical space reveals the psycho-historical reconstruction of the family, marriage and paternity. It is noted that the social content of the family, which is inscribed in the framework of the disposition of nepotism, indicated its socialization by the state, where regulation is carried out using the system of roles, norms, structural and functional organization of marriage and family practices and control over sexuality.

The processes of industrialization, the sexual revolution and women's emancipation have become a catalyst for changes in the views on marriage, family and paternity. According to the author, the liberalization of sexual relations in the context of the historical events of that time is aimed at destroying the "bourgeois" family as a social unit and egalitarian experiments: communes, free love and legitimizing the practices of the 
mono-mother family. It is noted that sexual relations without intent to continue another kind of connections - marriage and procreation - paternity found the instability of the matrix "disposition of family", which are considered as the beginning of the process of its deconstruction. The delimitation of sexual relations from reproductive function left the practice of sexual partnership outside the disposition of nepotism, thus laying new rules of behavioral culture in the sphere of marriage and family relations.

It is concluded that the disposition of nepotism as a matrix of changes in the practices of family, marriage and paternity cultivated by society, in a different social environment, is changing. The functioning of the practices of civil partnership and mono-mother families led to a break in relations: sexuality - reproduction and marriage - paternity, which are considered as signals of institutional transformations of the family, marriage and fatherhood. The delimitation of sexual practices from the disposition of the family in a historical perspective allowed the construction of configurations where the bond breaks: sex - gender not only diversified the functional-role relationships of men / women, but also indicated the depth of changes in the institutions of family, marriage and paternity.

Key words: family disposition; practices; civil partnership; mono-mother family; sex; gender.

\title{
ПЕРВООСНОВЫ ТРАНСФОРМАЦИЙ ПРАКТИК БРАЧНО-СЕМЕЙНОГО ПАРТНЕРСТВА И РОДИТЕЛЬСТВА
}

\author{
Яцина Елена Федоровна, \\ кандидат педагогических наук, доцент, \\ доцент кафедры психологии \\ Государственного высшего учебного заведения \\ «Ужгородский национальный университет», \\ Ужгород, Украина. \\ ORCID iD: https://orcid.org/0000-0003-0053-481 \\ yacunaolenafed2017@gmail.com
}

Аннотация. На примере брачно-семейных практик, как продуктов конструирования реальности определенного культурноисторического пространства, раскрывается психоисторическая реконструкция семьи, брака и родительства. Определено, что социальное содержание семьи, вписанное в рамки диспозиции семейности, указывает на ее обобществление государством, вследствие чего регулирование осуществляется системой ролей, норм, структурно-функциональной организацией брачно-семейных практик и контролем за сексуальностью. 
Процесс индустриализации, сексуальная революция и женская эмансипация стали катализатором изменений во взглядах на брак, семью и родительство. По мнению автора, либерализация сексуальных отношений в контексте исторических событий того времени была направлена на разрушение «буржуазной» семьи как социальной единицы и на эгалитарные эксперименты: коммуны, свободную любовь, легитимизацию практик мономатеринской семьи. Подчеркивается, что сексуальные отношения без дальнейшего заключения брака и продолжения рода - родительства - выявили нестойкость матрицы «диспозиция семейности», что рассматривается как начало процесса ее деконструкции. Разграничение сексуальных отношений от репродуктивной функции оставило практики сексуального партнерства за диспозицией семейности, таким образом закладывая новые правила культуры поведения в сфере брачносемейных отношений.

Определено, что прогностично информативными признаками трансформации практик брачно-семейного партнерства и отцовства являются социально-психологические предикторы смыслов практик: культурно-обусловленные, индивидуально-личностные, эмоционально-чувствительные.

Подводится итог о том, что диспозиция семейности, как матрица конфигураций культивированных обществом практик семьи, брака, родительства, в условиях другой социальности меняется. Функционирование практик гражданского партнерства и мономатеринских семей выявило разрыв связей сексуальность репродуктивность и брак - родительство, которые рассматриваются как сигналы институциональных трансформаций семьи, брака и родительства. Разграничение сексуальных практик от диспозиции семейности в исторической перспективе сделали возможным конструирование конфигураций, где разрыв связей пол - гендер не только разнообразил функционально-ролевые отношения мужчин/женщин, но и указал на глубину изменений институтов семьи, брака и родительства.

Ключевые слова: диспозиция семейности; практики; гражданское партнерство; мономатеринская семья; пол; гендер.

\section{REFERENCES (TRANSLATED AND TRANSLITERATED)}

[1] I. G. Belyavskij, Lekcii po istoricheskoj psihologi. Odessa, Ukraina: Astroprint, 2004, $448 \mathrm{~s}$. 
Вісник післядипломної освіти. Випуск 7(36) «Серія «Соціальні та поведінкові науки» https://doi.org/10.32405/2522-9931

[2] H. M. Bevz, Pryiomna simia: sotsialno-psykholohichni vymiry. Kyiv Ukraina: Slovo, 2010, 352 s.

[3] P. L. Berher, B. Berher, Shcho take instytutsiia? Vypadok movy, Nezalezhnyi kulturolohichnyi chasopys «I», № 35, 2004; per. Yu. Yaremko. [Elektronnyi resurs]. Dostupno : http://www.ji.lviv.ua/n35texts/35-zmist.htm.

[4] S. N. Gavrov, Istoricheskoe izmenenie institutov sem'i i braka. Moskva, Rossiya: NIC MGUDT, 2009, $134 \mathrm{s.}$

[5] YU. V. Gradskova, Obychnaya» sovetskaya zhenshchina - obzor opisanij identichnosti. Moskva, Rossiya: Sputnik, 1998, s. 362-364. [EHlektronnyj resurs].

Dostupno: http://kaznu.kz/content/files/pages/folder18187/Ю.B.\%20Градскова\%20 -\%200бычная\%20советская\%20женщина\%20.pdf

[6] S.V.Darmodekhin, «Sem'ya i gosudarstvo», Monitoring social'noehkonomicheskogo potenciala semej, № 3, s. 2-3, 2000.

[7] N. Ye. Donii, «Sotsialna devitalizatsiia osobystosti v hlobalizovanomu sviti: filosofska kontseptualizatsiia», avtoref. dys. na zdobuttia nauk. stupenia d-ra nauk; M-vo osvity i nauky Ukrainy; Nats. ped. un-t im. M. P. Drahomanova. Kyiv, Ukraina, 2015, 36 s.

[8] I.ZHerebkina, Sub"ektivnost' i gender: gendernaya teoriya sub"ekta v sovremennoj filosofskoj antropologii. Sankt-Peterburg, Rossiya, 2007, s. 260.

[9] M. Karmazina, O.Shurbovana, «"Instytut" ta "instytutsiia": problema rozriznennia poniat». Politychnyi menedzhment, № 4, s. 10-19, 2006.

[10] T. G. Kiseleva, ZHenskij obraz v sociokul'turnoj refleksii. Moskva, Rossiya: MGUKI, 2002, s. 210.

[11] Z. M. Kodar, «Predstaviteli francuzskogo feminizma o cennosti zhenskogo nachala» na II Mezhdunar. zaoch. nauch.-prakt. konf. Gendernye aspekty gumanitarnyh nauk (Rossiya, g. Novosibirsk, 21 noyabrya 2012 g.) [EHlektronnyj resurs]. Dostupno: https://sibac.info/conf/gender/iiii/30157

[12] D. A. Kutuzova, «Byt' sem'ej»: vzglyad s tochki zreniya social'nogo konstrukcionizma», Postneklassicheskaya psihologiya. Social'nyj konstrukcionizm i narrativnyj podhod, № 1(2), s.72-93, 2005. [EHlektronnyj resurs]. Dostupno: http://narrativepsy.narod.ru/num12005.html

[13] N. B. Lebina, M. V. SHkarovskij, «V otsutstvie oficial'noj prostitucii», Prostituciya v Peterburge (40-e gg. XIX v. - 40-e gg. XX v.). Moskva, Rossiya: Progress-Akademiya, 1994, 288 s., s. 40-59; 98-132.

[14] O. M. Oliinyk, «Hlokalizatsiia yak dialektychna yednist hlobalizatsii ta lokalizatsii» Hileia: naukovyi visnyk: zb. nauk. prats. № 24, s. 167-173, 2009. ISSN 2076-1554.06.

[15] T. Parsons, O social'nyh sistemah. Moskva, Rossiya: Akademicheskij proekt, $2002,832 \mathrm{~s}$. 
[16] Pol Riker, Istoriia ta istyna; per. z fr. V. I. Shovkun; T. S. Holichenko, Red. Kyiv, Ukraina: KM Academia: Pulsary, 2001, 393 s.

[17] E. YU. Rozhdestvenskaya, «Neformalizovannye dannye: metody sbora i analiza. Dokumental'nyj dostup k «sub"ektivnym mikroteoriyam» i obydennomu znaniyu», Cociologiya, № 33, s. 80-111, 2011. [EHlektronnyj resurs].

Dostupno: http://jour.isras.ru/upload/journals/6/articles/3722/submissio n/original/3722-6895-1-SM.pdf

[18] Yu. M. Savelieva, «Sotsialno-filosofske osmyslennia simeinykh zviazkiv v epokhu merezhevoho suspilstva: skhid proty zakhodu», Teoriia i praktyka upravlinnia sotsialnymy systemamy, № 1, s. 29-35, 2015.

[19] A. R. Tivodar, «Lichnost' kak sub"ekt so-bytiya v brachnyh otnosheniyah: avtoref. dis. na soiskanie uchenoj stepeni d-ra nauk»; Kubanskij gos. un-t. Krasnodar, Rossiya, 2008, 47 s.

[20] A.YA. Flier, Kul'turologiya dlya kul'turologov. Moskva, Rossiya: Akademicheskij Proekt, 2000, 496 s. ISBN 5-8291-0083-5

[21] M. Fuko, Istoriya seksual'nosti-III: Zabota o sebe; per, s fr. T. N. Titovoj i O. I. Homy; A. B. Mokrousova, Red. Kiev, Ukraina: Duh i litera; Grunt; Moskva, Rossiya: Refl-buk, 1998, 288 s. (Astrum Sapientiale).

[22] S. CHujkina, «Byt neotdelim ot politiki: oficial'nye i neoficial'nye normy polovoj morali v sovetskom obshchestve 1930-1980-h godov», V poiskah seksual'nosti: sbornik statej. E. Zdravomyslovoj i A. Temkinoj. Red. SanktPeterburg, Rossiya, 2002, s. 112.

[23] E. V.YAkimova, «Social'no-psihologicheskie aspekty sem'i i braka: teoriya i ehmpiriya», CHelovek: obraz i sushchnost'. Ezhegodnik. Sem'ya: Tradicii i sovremennye tendencii, RAN. INION, s. 215-243, 2007:

[24] P. Bourdieu, Męska dominacja / Tłum. L. Kopciewicz. Warszawa, 2004, s. 101. 